Int. J. Electrochem. Sci., 15 (2020) 12149 - 12159

International Journal of

ELECTROCHEMICAL

SCIENCE

$\underline{\text { WWW.electrochemsci.org }}$

\title{
Effect of Partial replacement of Portland cement with micro- silica on mechanical characteristics of concrete and corrosion behavior of mild steel in $1 \mathrm{M} \mathrm{HCl}$
}

\author{
Qin Wang ${ }^{1, *}$, Jian Xiong ${ }^{2}$ \\ ${ }^{1}$ College of civil engineering, Yancheng Institute of Technology, Yancheng 224000 Jiangsu Province, \\ China \\ ${ }^{2}$ Yancheng City Highway Engineering Test Center Co., Ltd., Yancheng 224000, Jiangsu Province, \\ China \\ *E-mail: wangqin2001_01@126.com, ganggaoxx8@163.com
}

doi: $10.20964 / 2020.12 .14$

Received: 13 July 2020 / Accepted: 23 September 2020 / Published: 31 October 2020

\begin{abstract}
The effect of micro-silica (MS) as Portland cement (PC) replacement on corrosion resistance of mild steel rebar were considered by open circuit potential (OCP), electrochemical impedance spectroscopy (EIS) and water absorption analysis after exposure to $1 \mathrm{M} \mathrm{HCl}$ solution. Compressive strength tests were done to investigate the mechanical property of the concrete samples. By increasing immersion time, all concrete samples containing MS indicated a reduction in water absorption value compared to the concrete sample without MS. The samples with $8 \mathrm{wt} \% \mathrm{MS}$ exhibited the highest compressive strength after 8 weeks exposure time in a $1 \mathrm{M} \mathrm{HCl}$ solution. The value of OCP for the steel reinforced concrete specimens with $8 \mathrm{wt} \% \mathrm{MS}$ remained in the uncertain or low corrosion zone during the process. The EIS results showed that the $8 \mathrm{wt} \% \mathrm{MS}$ sample had a higher the concrete resistance and charge-transfer resistance compared to other samples, showing lower porosity of concrete structure and thus more improvement in corrosion resistance of the mild steel surface. The SEM images of mild steel rebars revealed that the steel reinforced concrete with $8 \mathrm{wt} \%$ MS content had low corrosion and minimum pit products, indicating the slight pitting corrosion shaped on the surface of mild steel rebar, which was in agreement with the results obtained from electrochemical study.
\end{abstract}

Keywords: Partial replacement; Micro-silica; mild steel rebar; Electrochemical corrosion; Compressive strength; Water absorption; Acidic environment

\section{$\underline{\text { FULL TEXT }}$}

(C) 2020 The Authors. Published by ESG (www.electrochemsci.org). This article is an open access article distributed under the terms and conditions of the Creative Commons Attribution license (http://creativecommons.org/licenses/by/4.0/). 